GOSPODARKA SUROWCAMI MINERALNYMI - MINERAL RESOURCES MANAGEMENT

\title{
Hard coal project valuation based on real options approach: multiplicative vs. arithmetic stochastic process
}

\section{Introduction}

Investment projects developed in the mineral industry are exposed to numerous systematic and unsystematic (or specific) risks that significantly influence a project's feasibility and value. These often place a burden on decision making. The problem increases in complexity with the progress towards the liberalization of the electricity market. Due to the higher risk exposure of power companies, those enterprises bring particular attention to cost reductions, which have a direct impact on the mineral companies, mostly primary energy suppliers (Kamiński 2009, 2011). As a consequence, many mineral companies concentrate on producing the most precise project valuations possible in order to justify their choices. However, decision makers are usually not satisfied with the results of the most popular valuation methodology - discounted cash flow analysis (DCF) - because it does not recognize the value of managerial flexibility. This last factor represents the possibility to wait and/or modify operational strategies.

The most promising methodology of valuing flexibility is the real options analysis (ROA). Until the mid-90s, the method was known and recognized almost exclusively within closed academic circles. The perception of ROA has changed dramatically only in the last couple

* Professor, AGH University of Science and Technology, Department of Energy Management, Faculty of Management, Krakow, Poland; e-mail: psaluga@zarz.agh.edu.pl

** Professor, Mineral \& Energy Economy Research Institute, Polish Academy of Sciences,

Department of Policy and Strategic Research, Division of Energy Economics, Kraków, Poland;

e-mail:kaminski@min-pan.krakow.pl 
of decades. One of the most influential reasons was a significant simplification of ROA algorithms, which has been achieved through:

- incorporating lattice models (specifically binomial trees),

- introducing a single underlying instrument - the (gross) present value, PV, of a project, and

- making the following assumptions:

- the underlying asset follows geometric Brownian motion, GBM (specifically the multiplicative binomial process), with so called 'consolidated volatility',

- the levels of consolidated volatility and the risk-free rate are constant,

- in order to value a real asset in 'no arbitrage' terms one does not need to identify a marketed twin asset that replicates the payments that it makes - the twin asset of a project is the same project - but without managerial flexibility; this assumption, introduced by Copeland and Antikarov (2001), is called the 'marketed asset disclaimer' (MAD).

The issues noted above reveal, however, that in most cases models constructed on the abovementioned assumptions and modifications are not consistent with real projects (Guj 2011; Miranda and Brandão 2013), and one of the issues attracting the most criticism is the MAD premise. One may argue that project PVs might not follow a geometric Brownian motion (or the multiplicative stochastic process), which could have a direct impact on the final results and hence the correct estimation of the economic efficiency of the investment project in question. Thus, the objective of this paper is to discuss the most popular and widely accepted ROA valuation algorithm and to propose further modifications in order to construct models that provide a better fit to reality. The numerical case study provided presents and discusses the valuation of a hypothetical hard coal project with a sequential time-to-build option and an option-to-expand.

Initially, to illustrate the problem, we calculate the strategic project value in the multiplicative binomial tree model of the classical MAD approach. Then, the model is modified - the multiplicative tree was replaced with an additive one. We show how to assess an 'additive volatility' and to develop 'dividend' adjustments in the additive scheme enabling the tree to recombine. In the end, we propose the 'consecutive' (primary and secondary) modeling of an underlying asset and then the valuation of the project applying the standard approach.

\section{The classical 'MAD approach'}

The classical Copeland-Antikarov 'MAD approach' (Copeland and Antikarov 2001) assumes that the underlying instrument of real options is a gross present value, PV. PV is calculated in a 'static' DCF spreadsheet as a sum of net present value, NPV, and discounted capital expenditure. PVs evolve with time according to the standard stochastic process geometric Brownian motion - which, in its discrete binomial version, transforms into the Cox-Ross-Rubinstein's (1979) multiplicative stochastic process (Fig. 1). 


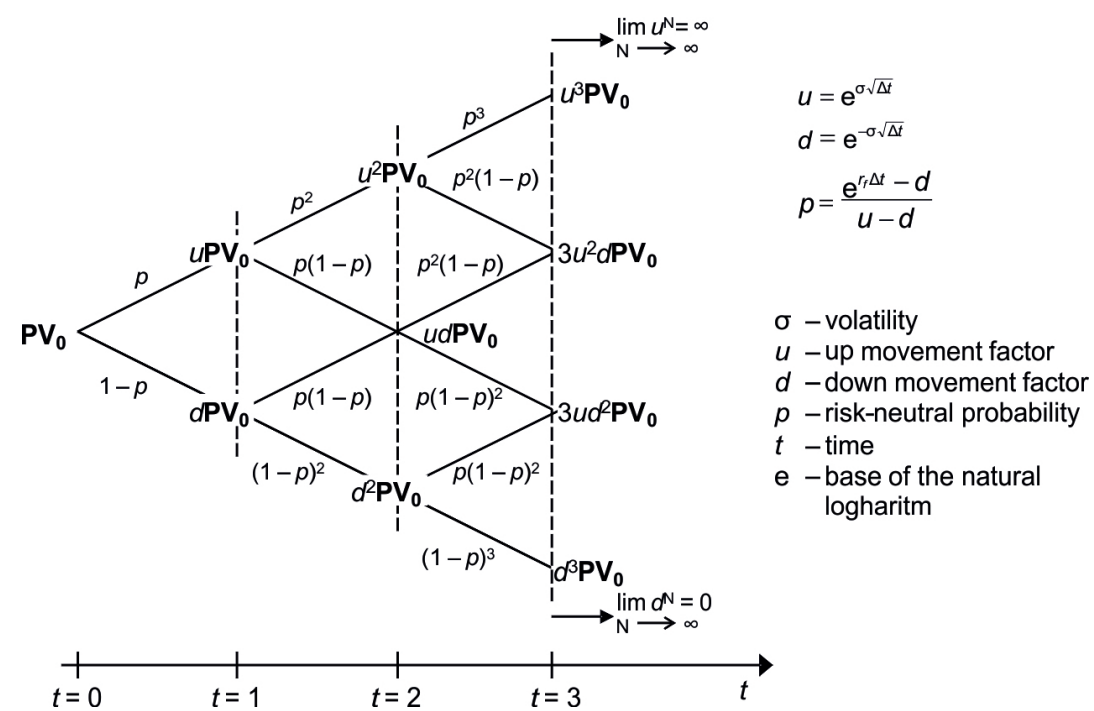

Fig. 1. The multiplicative binomial process

Rys. 1. Iloczynowy process stochastyczny

The idea that the underlying instrument of real assets follows geometric Brownian motion is taken directly from financial options. This process, coming from arithmetic Brownian motion, was developed to describe the changes of prices (of a product or commodity) with time. This pattern of uncertain asset behavior was then, by analogy, adopted by most real options practitioners. The characteristic feature of the GBM/multiplicative process is that the underlying asset never takes a negative value. At the limit, as the number of steps tends to infinity, the end outcomes of the multiplicative tree approach a lognormal distribution.

Assuming that the only underlying asset is $\mathrm{PV}$, we must be aware that the present value of the project is influenced by many sources of uncertainty (mainly prices, costs and production volumes). Nevertheless, introducing a single underlying asset is convenient for the practitioner - it helps us to escape from the problem of rainbow options and the complicated modeling of real assets in multinomial trees. However, it makes it necessary to assess the volatility of the aggregate PV (project) - this problem was solved through developing the logarithmic present value returns approach (LPVR) that uses the Monte Carlo simulation. The LPVR is most commonly used in the MAD approach - one may find interesting details in various publications (e.g. Copeland and Antikarov 2001; Mun 2006; Knopf and Teall 2015; etc.).

\section{The project}

A foreign company YSSY plans to build a new hard coal mine in Poland. The company has obtained an exploitation license and other required permits. Furthermore, a Competent 
Person (a professional defined by the JORC Code - JORC, 2012) has reported the marketable hard coal reserves within concession at 100 million tonnes. The new mine is assumed to operate with a target yearly output of 5.06 million tonnes of gross coal; the coal recovery is estimated at $85 \%$, which means a production of 4.30 million tonnes of marketable coal per year. It has been assumed that in the first year of operation (year 3), the mine is going to operate at $50 \%$, whilst in the last 3 years of the project's lifetime - until the plant's closure - the enterprise will run at $75 \%, 50 \%$ and $25 \%$ of its target capacity.

The project's lifetime has been estimated to be around 27 years, including the construction of the mine and the deposit development (in total 3.5 years).

Capital expenditures, including construction and development costs, were estimated at 834.27M PLN. A straight-line depreciation was assumed. It is presumed that the working capital (100M PLN) needed in the 1st year will be recovered at the end of the project's lifetime.

Operation costs (OPEX) were assessed as follow:

- basic cash OpCosts (excluding depreciation and waste development): 231.20 PLN/tonne of output,

- waste utilization cost: 16.70 PLN/tonne.

The mine's closure cost has been estimated at 75M PLN. According to Polish law (Polish Geological and Mining Law 2011), the mine must build an interest-bearing closure fund which comprises subsequent payments (deducted from revenues) in excess of 3-9\% of yearly depreciation. Assuming a 2.5\% (real) risk-free interest rate, YSSY decided that a 7\% deduction will be a satisfactory rate to allocate disposable funds for the mine's closure - at the time of liquidation the expected balance on the account will be around 79.72M PLN.

The long-term average flat price of marketable coal has been estimated at $300 \mathrm{PLN} /$ tonne of marketable coal.

The risk-adjusted discount rate (100\% equity, real) was estimated at 15\% (Smith 1994, 2000).

The DCF spreadsheet (Table 1) was calculated in constant values. It was assumed that $40 \%$ of the project will be financed with debt at a nominal interest rate of $6.8 \%$, which results in $4.2 \%$ real. The weighted average cost of capital (real), including $19 \%$ tax shield, has been estimated then at $7.5 \%(\mathrm{WACC}=0.4 \times 0.042(1-0.19)+0.6 \times 0.15)$.

The calculated net present value of the project is positive (PLN 1.86 M). This value was obtained by calculating the gross present value at $15 \%$ discount rate (PV equals PLN $794.63 \mathrm{M}$ ) and then reducing it by the discounted values (at a $2.5 \%$ risk-free rate) of capital expenditure (PLN 792.77 M in total).

The DCF decision criteria is clear - NPV $>0$ so the project should be initiated immediately. The management, however, having the results of the sensitivity and scenario analyses, views it as fairly risky. Fortunately, due to specific determinants, the management has the possibility of waiting one year for the project start up. Additionally, the new project creates the opportunity to expand the production of the proposed unit - the YSSY's analysts expect a sluggish increase of hard coal prices during the coming years. Due to this, the company is considering the option to expand the production within the first 4 years of plant operation. 
4

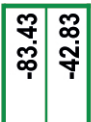

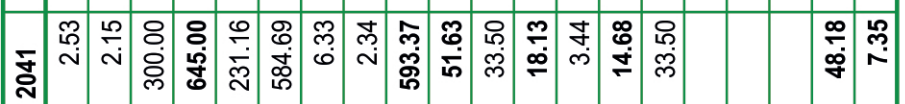

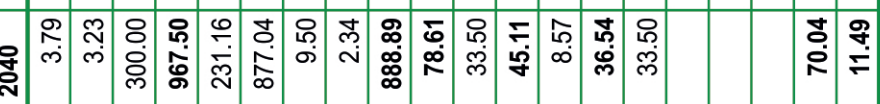

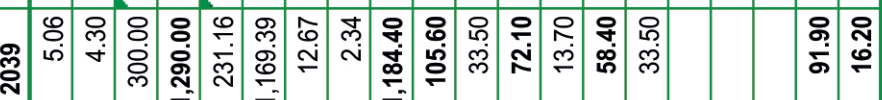

氵亏

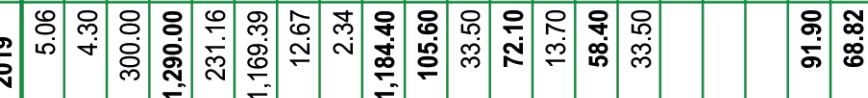

赵

疋

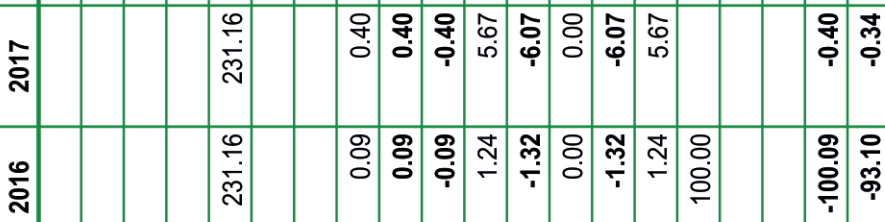

ลั้

:

苞

可

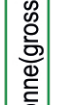

氛产

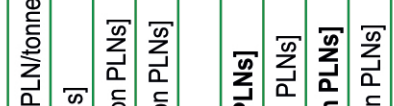

$\overrightarrow{2}$

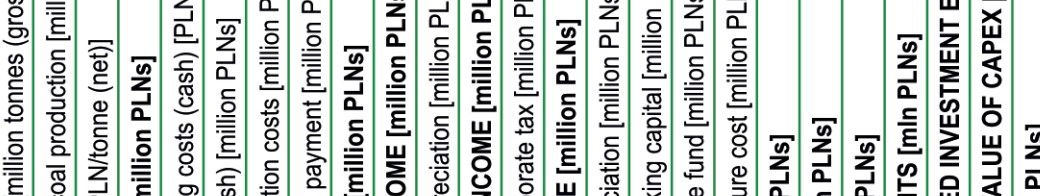

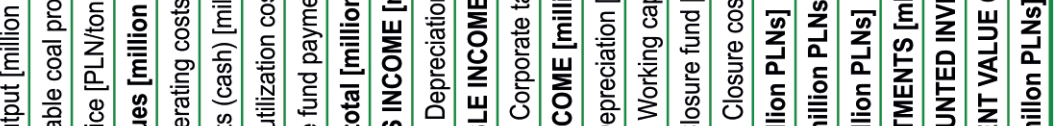


The experts assess that it may result in a 50\% increase in value. In order to make it possible, the company must pay an additional cost of PLN 415 M (constant zlotys).

\section{Valuation of the project in the multiplicative model}

Generally, YSSY's know-how about hard coal mining is well established, well proven and well developed. Having a large quantity of data available, the company's analysts evaluated the consolidated volatility of the project using the above-mentioned LPVR approach. The PV's volatility was assessed at $15 \%$, so up- and down- factors are 1.16 and 0.86 respectively. Risk-neutral probability, calculated on the basis of the MAD assumption, stands at 0.56 .

As mentioned before, YSSY's hard coal project is a venture with two real options (Table 2):

- a sequential time-to-build option, that involves four options-to-wait,

- an option-to-expand.

Table 2. Real options parameters of the YSSY's project

Tabela 2. Parametry opcji rzeczowych projektu spółki YSSY

\begin{tabular}{|c|c|c|c|c|c|c|}
\hline \multirow{2}{*}{\multicolumn{2}{|c|}{$\begin{array}{l}\text { Name and a number of } \\
\text { the option }\end{array}$}} & \multicolumn{2}{|c|}{ Option lifetime } & \multicolumn{2}{|c|}{ Exercise price } & \multirow{2}{*}{$\begin{array}{l}\text { Terminate-node } \\
\text { formula }\end{array}$} \\
\hline & & [years] & [period] & [specification] & {$[\mathrm{M}$ PLN]* } & \\
\hline \multicolumn{2}{|c|}{ Option-to-expand (V.) } & 4 & yr $4-y r 7$ & $\begin{array}{l}\text { Cost of additional } \\
\text { production, } K\end{array}$ & 688.51 & $\begin{array}{c}\max \left(1.5 \mathrm{PV}_{7 . \mathrm{X}}-K\right) \\
{[1.5=\text { expand factor }]}\end{array}$ \\
\hline \multirow{4}{*}{$\begin{array}{l}\text { Time- } \\
\text { to-build } \\
\text { option } \\
\text { (IV.-I.) }\end{array}$} & phase 4 (IV.) & 1 & yr $3-y r 4$ & CAPEX $4, I_{4}$ & 250.59 & $\max \left(\mathrm{PV}_{4 . \mathrm{X}}-I_{4} ; 0\right)$ \\
\hline & phase 3 (III.) & 1 & yr $2-$ yr 3 & CAPEX $3, I_{3}$ & 455.61 & $\max \left(\mathrm{PV}_{3 . \mathrm{X}}-I_{3} ; 0\right)$ \\
\hline & phase 2 (II.) & 1 & yr $1-$ yr 2 & CAPEX $2, I_{2}$ & 118.67 & $\max \left(\mathrm{PV}_{2 . \mathrm{X}}-I_{2} ; 0\right)$ \\
\hline & phase 1 (I.) & 1 & yr $0-$ yr 1 & CAPEX $1, I_{1}$ & 34.43 & $\max \left(\mathrm{PV}_{1 . \mathrm{X}}-I_{1} ; 0\right)$ \\
\hline
\end{tabular}

* Values in the year of expiration; for the needs of option value calculations for each year the values of $K$ were capitalized at the $7.5 \%$ WACC rate; values of $I$ were updated using the $2.5 \%$ risk-free rate

Figure 2 presents the multiplicative binomial tree of the underlying asset for the first 7 years. Assuming that the YSSY's managers have the possibility to wait and see for one year, the project's first cash flows ('dividends') may be received in year 4 .

Calculations of the option value of the project are presented in Figure 3. We start with the last (expanding) option, beginning from the final nodes (year 7), and then go in the usual way - recursive backwards calculation - to the initial point (node 0.1, year 0). The real option values (ROV) were calculated with the traditional (risk-neutral probability approach) formula: 


$$
\operatorname{ROV}_{\mathrm{X}}=\frac{\mathrm{ROV}_{\mathrm{X}+1}^{\mathrm{up}} \cdot p+\mathrm{ROV}_{\mathrm{X}+1}^{\mathrm{down}} \cdot(1-p)}{1+r_{f}}
$$

In nodes where cash flows occur, the resulting ROVs (denoted as 'ex' - 'ex-dividend') have to be adjusted to 'cum-dividend' values with a CF/PV ratio calculated with the use of expected values on a DCF spreadsheet. The tree obtained as a result of calculating the preceding option serves as the underlying scheme for the calculation of the succeeding one.

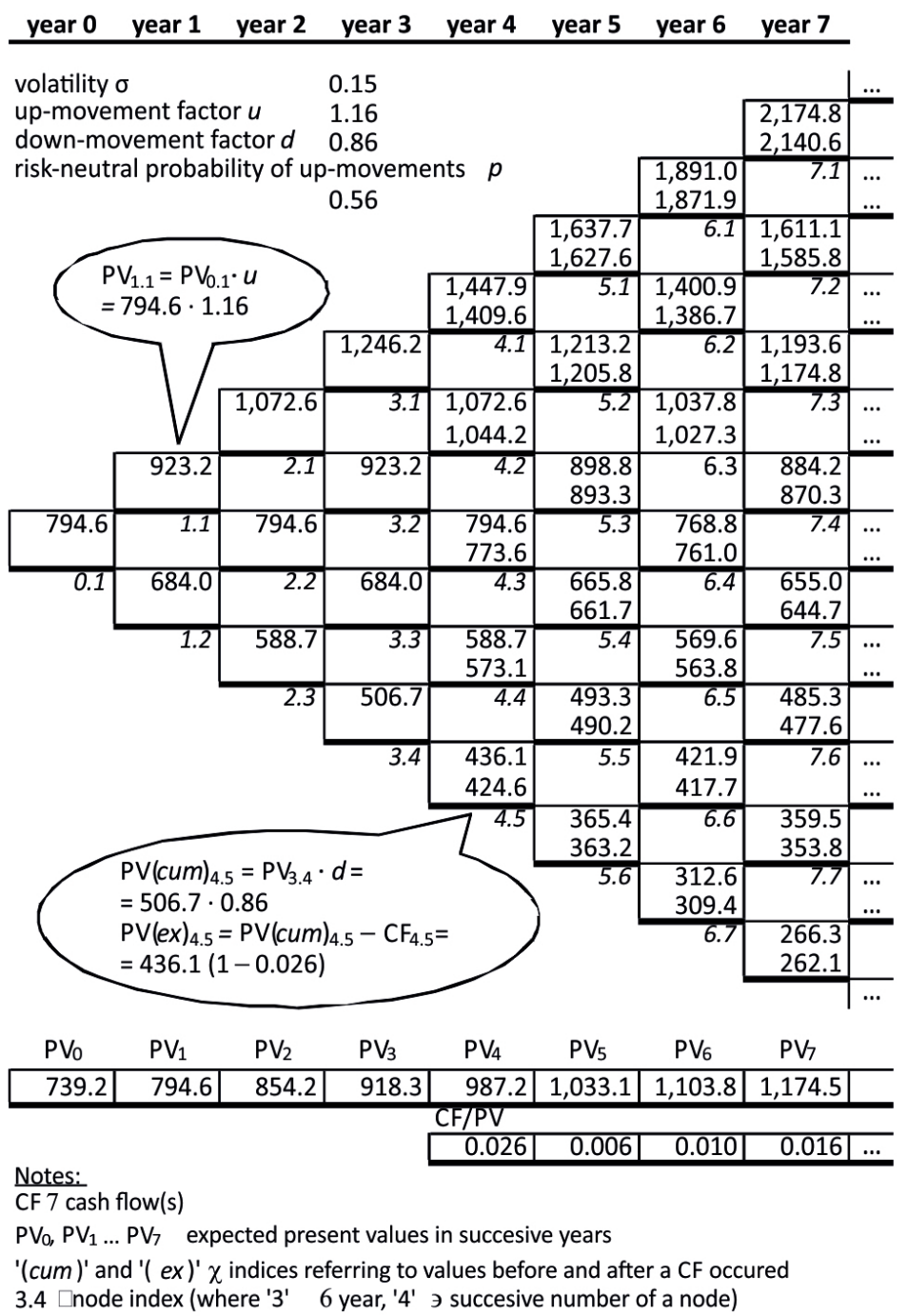

Fig. 2. Multiplicative binomial tree of the underlying asset (PV) of the YSSY's hard coal project

Rys. 2. Iloczynowe drzewo dwumianowe instrumentu bazowego (PV) projektu węglowego spółki YSSY 


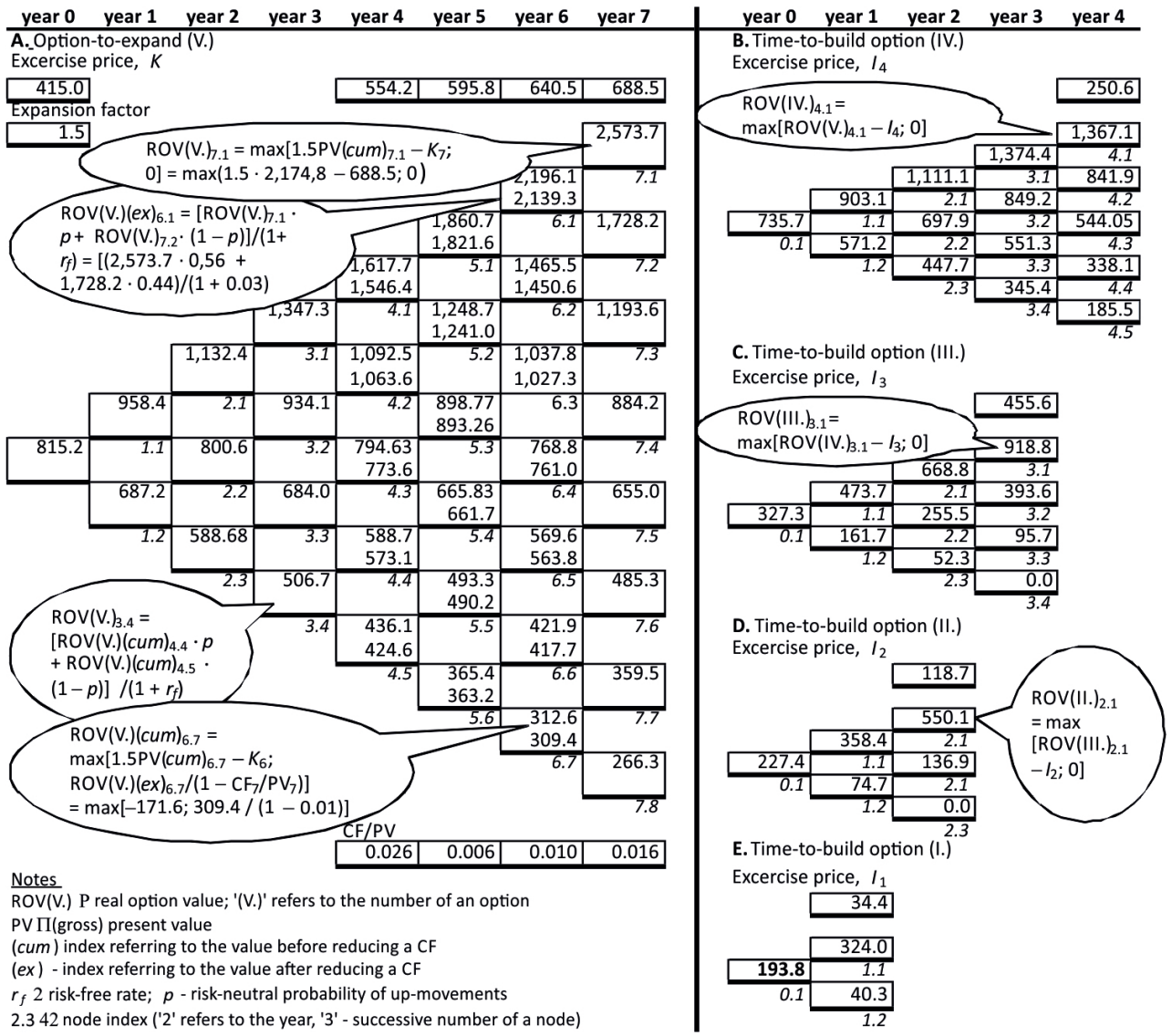

Fig. 3. Valuation of the YSSY's hard coal project in the multiplicative binomial model

Rys. 3. Wycena projektu węglowego spółki YSSY w iloczynowym modelu dwumianowym

The ultimate real option value of the project, also called the strategic or expanded net present value (XNPV), is PLN 193.8M. The value of managerial flexibility (option premium, $\mathrm{OP}=\mathrm{XNPV}-\mathrm{NPV}$ ) is then exorbitant - it equals 192.1M PLN.

\section{Real options analysis in the additive binomial model}

The first application of the stochastic process to describe the fluctuations in stock prices was proposed by Bachelier (1900). Bachelier assumed, however, that the stock price movements evolve with arithmetic Brownian motion, $\mathrm{ABM}$ - this means, in consequence, that the stock price might be negative which, of course, is nonsensical. Hence, Osborne $(1959,1962)$ and - independently - Samuelson (1965) modified the stochastic process by introducing the idea of geometric Brownian motion (GBM) - under GBM prices cannot be negative. 
The idea that stock prices follow a geometric Brownian motion became the basis for the valuation of financial options (Black and Scholes 1973) and was, as it were, automatically adopted by the real options theory. It was reasonable because the first real options models used prices as underlying assets.

As we stated before, introducing a single, consolidated underlying instrument of PV significantly simplified the valuation process in the real options analysis. This assumption, however, ignores the obvious fact that the project may take on negative values (occurrence of losses where operating costs exceed price levels). The problem was recognized by the authors of the PV approach but not discussed.

Because present values of the real asset may go negative, one should pose the question whether one should return to arithmetic Brownian motion.

A discrete approximation of ABM is an additive stochastic process. In the additive process, two subsequent possible values of the process are:

- the sum of the preceding value and the up-movement factor $u$,

- the difference between the preceding value and the down-movement factor $d$.

The modeling of the additive tree is complex - the stochastic process refers here not to asset returns but to increases in value. The main problem, however, is keeping equal probabilities across the tree. Among all additive models, only one fulfils this requirement - the symmetric additive tree, where jumps and probabilities within the tree are equal (the idea of it is presented in Figure 4). The symmetric additive tree of the YSSY's hard coal project is shown in Figure 5.

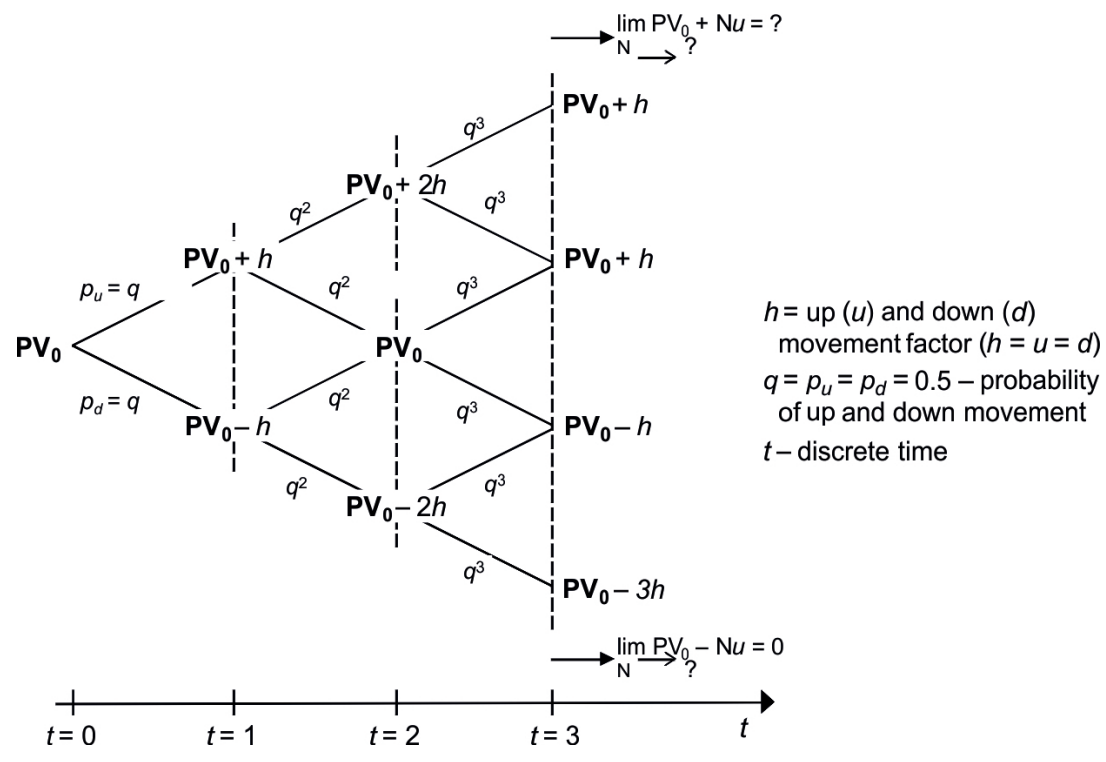

Fig. 4. The symmetric additive process

Rys. 4. Symetryczny proces addytywny 


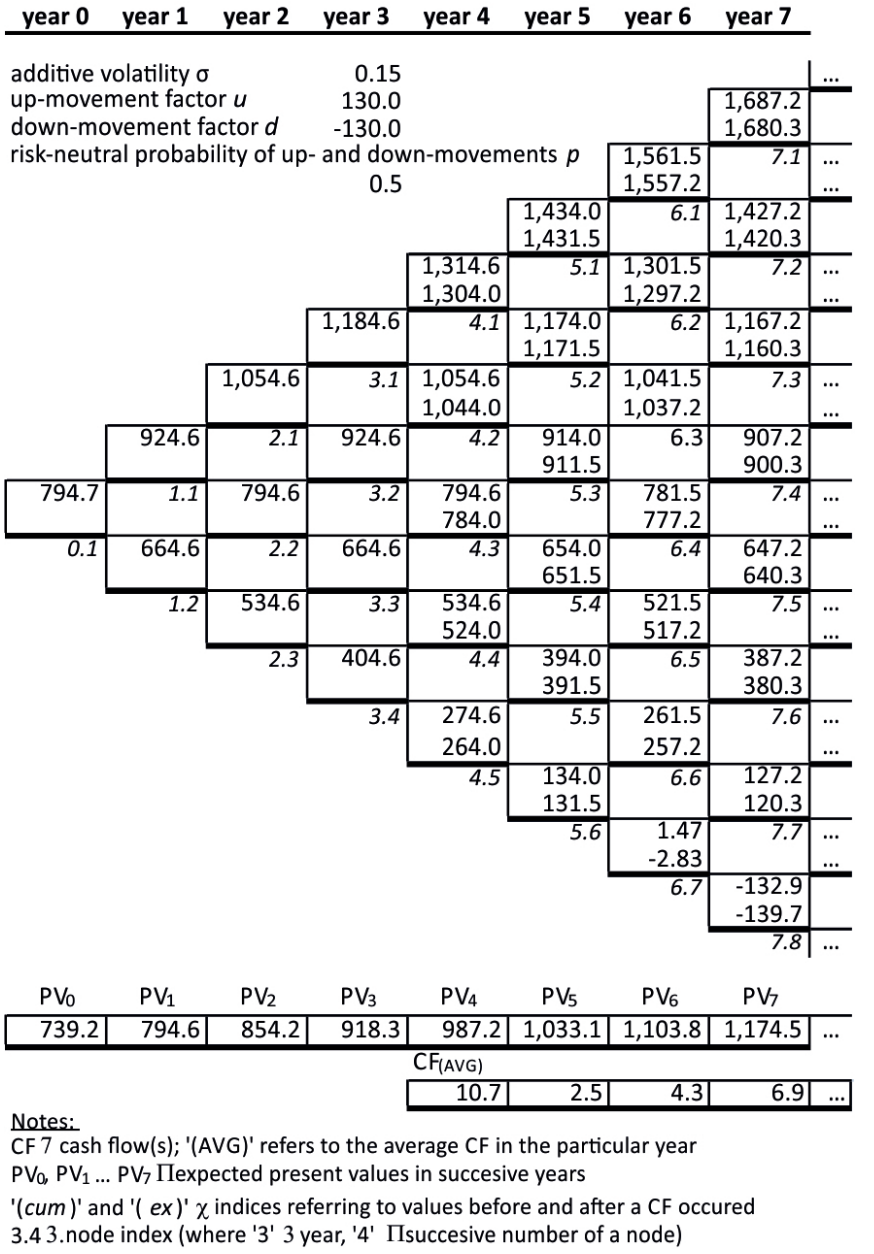

Fig. 5. Additive binomial tree of the underlying asset (PV) of the YSSY's hard coal project

Rys. 5. Addytywne drzewo dwumianowe instrument bazowego (PV) projektu węglowego spółki YSSY

The up and down movement factors were derived from a figure of 'additive volatility' evaluated by YSSY's analysts. The method of evaluating this volatility with the use of the Monte Carlo simulation is called the 'present value increments approach' or PVI (Saługa 2011). This assumes that the actual $\mathrm{PV}_{\mathrm{X}}$ may, in the next period, increase to

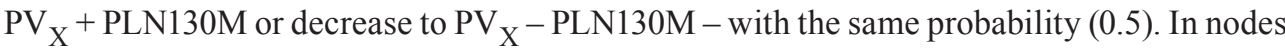
where 'dividends' (i.e. cash flows) appear, the PV 'cum'-dividend values have been adjusted to 'ex'dividend ones by reducing the former with the average expected PV obtained in the DCF spreadsheet. The final values have been derived using the 'corrections' of all the project's cash flows which enables one to get the specific PV values in specific nodes. We have used 'average' values in order to make the additive tree recombining.

Calculations of the project in the additive model are given in Figure 6. 


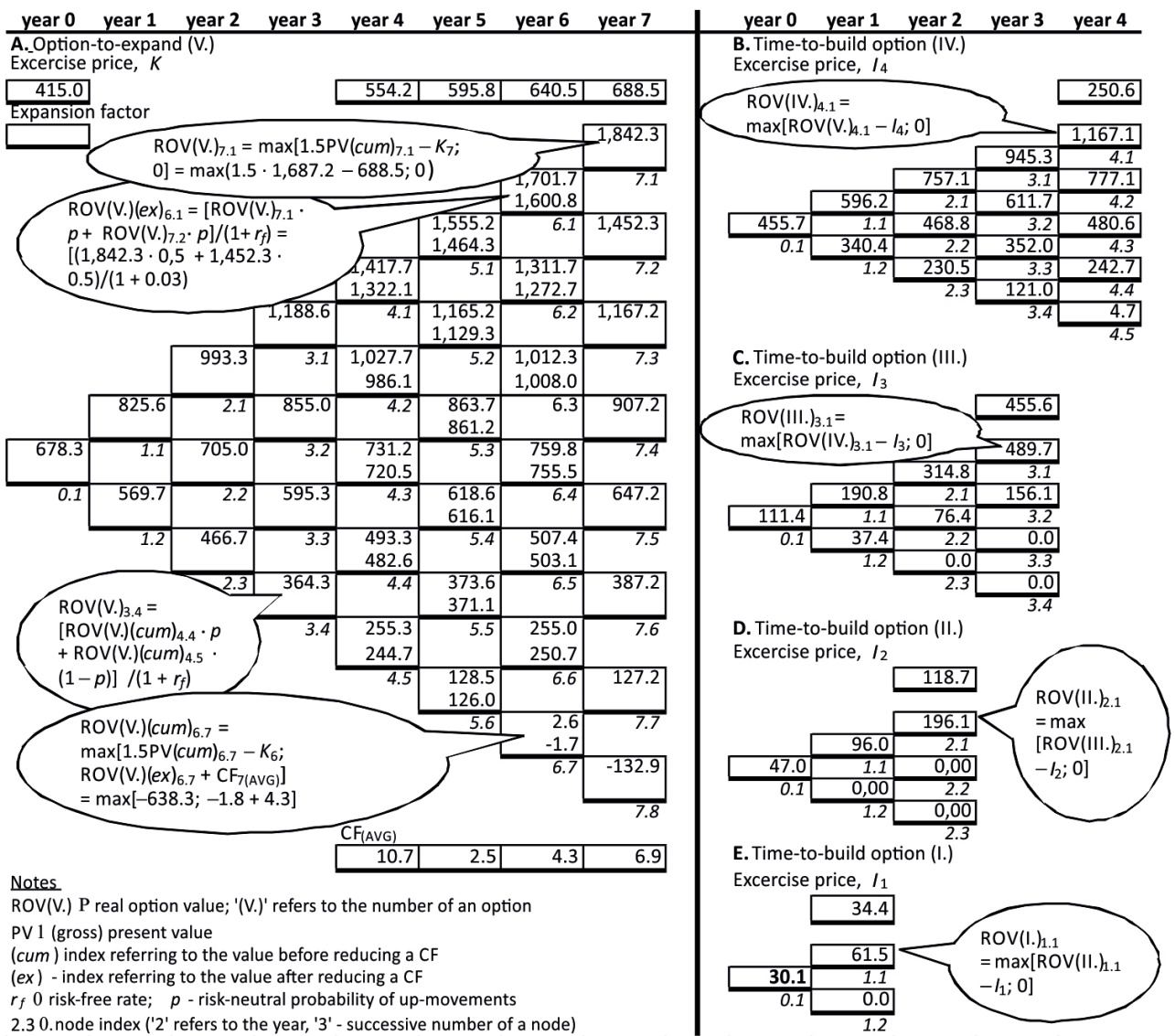

2.30 . node index (' 2 ' refers to the year, ' 3 ' - successive number of a node)

Fig. 6. Valuation of the YSSY's hard coal project in the additive binomial model

Rys. 6. Wycena projektu węglowego spółki YSSY w addytywnym modelu dwumianowym

These calculations show that the strategic (XNPV) value of the study project stands at PLN30.1M; the value of flexibility related to the opportunity to wait and expand (OP) amounts to $\$ 28.2 \mathrm{M}$. The 'additive' results are then quite different from the 'multiplicative' ones, complicating and confusing the decision problem for YSSY's management. The company's CEOs know that there is a potential for additional value but they still don't know how large that would be.

\section{Conclusions}

The mineral sector is an industry where making business involves being faced with high business-specific risk that creates a broad range of managerial flexibility which is not considered with classical DCF/NPV methodology. The value of flexibility may be, however, 
an important component of a project's value, so it should not be ignored. The promising potential for the valuation of managerial flexibility provides the real options analysis which involves many methods and approaches.

Recently, the generally accepted method of real options valuation has become the socalled 'MAD approach'. This method, apart from the main assumption ('marketed asset disclaimer'), incorporates a (gross) present value, $\mathrm{PV}$, of the real asset as a single underlying instrument. Additionally, the approach assumes that PV evolves with time according to a multiplicative stochastic process (being a discrete approximation of geometric Brownian motion, GBM) with so called 'consolidated volatility', which reflects, in general, a project's uncertainty.

Making an assumption about the multiplicative stochastic process produces the result that the present value never goes negative which is, in fact, untrue. An alternative scheme, from which GBM was derived, is arithmetic Brownian motion (ABM), with its discrete approximation called the additive stochastic process. This process enables values to go negative, which seems to be more realistic. Modeling changes of PV with time in this way is more convoluted than with the use of GBM but, nevertheless, the advantages of the ABM process in terms of the description of the changes in the underlying asset in option pricing models have already been proposed by a number of authors (e.g. Poitras 1998; Trojanowska and Kort 2005).

Nevertheless, using the additive stochastic process for modeling changes of present value is also questionable. A simple example can show that, in fact, realistic changes of a project's present value neither match GBM nor ABM (Saługa 2011).

Applying an additive stochastic process may produce more confusion - our calculations confirmed that the strategic value (XNPV) of an additive model may be diametrically different from that obtained from a multiplicative one. This problem results mainly - but not only - from volatility, which is, therefore, the most important parameter in flexibility and real options valuation (Haahtela 2010).

The question is which stochastic motion more closely matches the reality - what to use if not the geometric nor the additive one? First doubt refers to the stochastic process scheme we investigated only the most popular ones from a range of different motions. We set some simplifications, such as the assumption on tree recombining. They greatly ease the burden of calculations, but may deface the reality. The goal of this paper was to address a complex question, as the solution of the problem is, in fact, not trivial. One may perceive it even as highly sophisticated (Dehghani et al. 2014), so the analytic resolving of the question will be the task of further studies based on real industrial data.

This paper was partially performed within the statutory research program of the Mineral and Energy Economy Research Institute, PAS 


\section{REFERENCES}

Bachelier, L. 1900. “Theory of Speculation” (in French: “Théorie de la speculation”). Annales Scientifiques de l'Ecole Normale Supérieure 17, pp. 21-86.

Black, F. and Scholes, M. 1973. "The Pricing of Options and Corporate Liabilities" Journal of Political Economy 81, Chicago, Illinois.

Copeland, T. and Antikarov, V. 2001. Real Options: A Practitioner 's Guide. Texere, Thompson Corporation, pp. 370.

Cox, J.C., Ross, S.A. and Rubinstein, M. 1979. “Option Pricing: a Simplified Approach”. Journal of Financial Economics Vol. 7, No. 3, pp. 229-263.

Guj, P. 2011. A Practical Real Option Methodology for the Evaluation of Farm-In/But Joint Venture Agreements in Mineral Exploration, Resources Policy Vol. 36. pp. 80-90.

Dehghani, H. Ataee-pour, M. and Esfahanipour, A. 2014. Evaluation of the Mining Projects Under Economic Uncertainties Using Multidimensional Binomial Tree. Resources Policy Vol. 39, no. 1, pp. 124-133.

Haahtela, G.J. 2010. Recombining Trinomial Tree for Real Option Valuation with Changing Volatility. Aalto University, Working Paper Series, pp. 1-25.

JORC, 2012. Australasian Code for Reporting of Exploration Results, Mineral Resources and Ore Reserves (The JORC Code) [online], http://www.jorc.org (The Joint Ore Reserves Committee of The Australasian Institute of Mining and Metallurgy, Australian Institute of Geoscientists and Minerals Council of Australia).

Kamiński, J. 2009. The impact of liberalisation of the electricity market on the hard coal mining sector in Poland, Energy Policy Vol. 37, Issue 3, pp. 925-939.

Kamiński, J. 2011. Market power in a coal-based power generation sector: The case of Poland. Energy Vol. 36, Issue 11, pp. 6634-6644.

Knopf, P.M. and Teall, J.L. 2015. Risk Neutral Pricing and Financial Mathematics: A Primer. Academic Press, Elsevier, $333 \mathrm{pp}$.

Miranda, O. and Brandão, L.E. 2013. A Real Option Model To Value An Exploration Mining Project: An Application [Online] Availade at: http:/www.realoptions.org/openconf2014/data/papers/25.pdf [Accessed: 20.01.2016].

Mun, J. 2006. Real Options Analysis - Tools and Techniques for Valuing Strategic Investments and Decisions. Wiley, Hoboken, New Jersey, pp. 290.

Osborne, M.F.M. 1959. Brownian Motion in the Stock Market. Operations Research, 7, 145.

Osborne, M.F.M. 1962. Periodic Structure in the Brownian Motion of Stock Prices. Operations Research, 10, 345.

Poitras, G. 1998. Spread Options, Exchange Options and Arithmetic Brownian Motion. J. Futures Markets 18, 487-517.

Polish Geological and Mining Law, Act of 9 June 2011

Samuelson, P.A. 1965. A Rational Theory of Warrant Pricing. Industrial Management Review. In Collected Works of Paul Samuelson, Vol. 2, MIT Press.

Saługa, P. 2011. Managerial Flexibility in Mineral Project Valuation (In Polish: Elastyczność decyzyjna w procesach wyceny projektów geologiczno-górniczych). Studia, Rozprawy, Monografie nr 167, Wyd. IGSMiE PAN, 269 pp.

Smith, L.D. 1994. Discount Rates and Risk Assessment in Mineral Project Evaluations. Transactions Institution of Mining \& Metallurgy (Sect. A: Mineral Industry).

Smith, L.D. 2000. Discounted Cash Flow Analysis and Discount Rates. Special Session on Valuation of Mineral Properties Mining Millennium 2000, March 8, Toronto, Ontario.

Trojanowska, M. and P.M., Kort. 2005. Arithmetic Brownian Motion and Real Options. [In:] Proceedings of the 9th Annual International Conference 'Real Options - Theory meets Practice', Paris. 


\title{
WYCENA PROJEKTU WĘGLOWEGO Z WYKORZYSTANIEM ANALIZY OPCJI RZECZOWYCH
} W SCHEMACIE ILOCZYNOWEGO I ARYTMETYCZNEGO PROCESU STOCHASTYCZNEGO

\author{
Słowa kluczowe
}

górnicze projekty inwestycyjne, wycena, opcje rzeczowe, procesy stochastyczne

\section{Streszczenie}

Wycena efektywności ekonomicznej projektów inwestycyjnych w sektorze surowców mineralnych - charakteryzujących się zazwyczaj wysokim poziomem ryzyka - bezpośrednio wpływa na podejmowanie decyzji w zakresie realizacji przyszłych inwestycji. W ostatnich latach coraz większa liczba spółek dostrzega - w odniesieniu do dylematów rozstrzygania procesów decyzyjnych - znaczenie możliwości elastycznego reagowania menadżerów na zmiany zachodzące w otoczeniu przedsiębiorstw i w nich samych (elastyczność decyzyjna). Znaczenie to wyraża się w konkretnych kwotach pieniężnych - niestety, stosowana powszechnie w procesach wyceny przedsięwzięć analiza zdyskontowanych przepływów pieniężnych (DCF) oszacowania wartości elastyczności decyzyjnej nie umożliwia. Wycenę taką umożliwia natomiast zespół technik występujących w obrębie tzw. analizy opcji rzeczowych (real options analysis, ROA); upowszechnienie tej ostatniej następuje wskutek istotnego uproszczenia jej algorytmów, które zostało osiągnięte głównie przez:

- wprowadzenie tzw. modeli kratownicowych (drzew wielomianowych),

- wprowadzenie jako instrumentu bazowego projektów pojedynczego parametru w postaci wartości zaktualizowanej brutto (present value, PV) lub przychodów brutto,

- przyjęcie założenia, że aktywa bazowe rozwijają się w czasie zgodnie z iloczynowym procesem stochastycznym (stanowiącym dyskretną aproksymację geometrycznego ruchu Browna),

- przyjęcie założenia marketed asset disclaimer (MAD), stanowiącego, że instrumentem bliźniaczym waloru bazowego jest oszacowana w sposób klasyczny (DCF) wartość bieżąca projektu; pozwala to na wycenę przedsięwzięć w wrunkach braku arbitrażu.

Niestety, w większości przypadków modele zbudowane zgodnie z wyżej wymienionymi założeniami i zmianami nie odpowiadają rzeczywistości. Niektórzy badacze i analitycy stoją na stanowisku, że iloczynowy opis zmian wartości PV projektu jest niewłaściwy, co w konsekwencji może mieć znaczenie dla wartości i efektywności projektu. W odniesieniu do powyższego, w artykule przedstawiono zmodyfikowaną wersję popularyzowanego modelu, w którym iloczynowe drzewo zastąpione zostało addytywnym z propozycją zastosowania „zmienności addytywnej” oraz korekt z uwagi na „dywidendę”, czyli postępującą redukcję wartości PV o wartości poszczególnych przepływów pieniężnych. 


\section{HARD COAL PROJECT VALUATION BASED ON REAL OPTIONS APPROACH:} MULTIPLICATIVE VS. ARITHMETIC STOCHASTIC PROCESS

\section{Keywords}

mineral projects, valuation, real options, stochastic processes

Abstract

Precise valuation of the economic efficiency of risky investment projects in the mineral sector has a direct impact on the range of future investments. Since the mid-90s, a number of enterprises have also been giving increased attention to the valuation of managerial flexibility that cannot normally be estimated with classical discounted cash flow (DCF) analysis. This has been the result of a development in the real options analysis (ROA) and the simplification of its algorithms, most of which have been achieved through:

- incorporating lattice models,

- introducing a single uncertain project parameter (gross present value, PV) as an underlying instrument,

- assuming that the underlying asset follows the multiplicative stochastic process,

- introducing the 'marketed asset disclaimer' (MAD) assumption.

Unfortunately, in most cases, models constructed on the abovementioned assumptions and modifications are not consistent with real projects. Some analysts recognize that project PVs might not follow the multiplicative process, which could have a direct impact on the project's value. In order to improve the MAD approach, the paper proposes a modified model where the multiplicative tree is replaced with an additive one. In addition, methods of 'additive volatility' calculation and 'dividend' adjustments were suggested. 
